\title{
Membimbing Umat Melalui Program Ngaji Bisnis di Lembaga Sosial Teras Dakwah
}

\author{
Ahmad Syamsul Muarif \\ Universitas Islam Negeri (UIN) Sunan Kalijaga \\ ahmadsyamsul.m97@gmail.com \\ Iin Handayani \\ Universitas Islam Negeri (UIN) Sunan Kalijaga \\ iinhandayani618@gmail.com
}

\begin{abstract}
The purpose of this article is to examine the "study business" program as a new idea in boosting the interest of young people who want to become more religious, wealthier, successful, on the pilgrimage, and enter heaven. This article uses descriptive qualitative research, data collection methods through observation and interviews, with analysis techniques using data reduction, data presentation and drawing conclusions. The results showed that the process of implementing the "study business" program in the Da'wa Terace was by telling stories about the actions of business by Gus Madkhan and Haji Thariq, giving material from bankruptcy, having a lot of debt, giving alms to rising and building businesses to become successful. With this program, young people are interested in trying to open a business or open business opportunities in order to achieve success, become rich so that they can give alms more, can go on pilgrimage, become pious people and then go to heaven.
\end{abstract}

Keywords: secret of success, da'wa terace, study business

\begin{abstract}
Abstrak
Tujuan artikel ini ialah mengkaji tentang program "Ngaji Bisnis" sebagai ide baru dalam mendongkrak ketertarikan anak muda yang ingin menjadi lebih religius, kaya, sukses, naik haji, dan masuk surga. Artikel ini menggunakan jenis penelitian deskriptif kualitatif, metode pengumpulan data melalui observasi dan wawancara, dengan teknik analisis menggunakan reduksi data, penyajian data dan penarikan kesimpulan.
\end{abstract}


Hasil penelitian menunjukkan bahwa proses pelaksanaan program "Ngaji Bisnis" di Teras dakwah adalah dengan cara bercerita mengenai sepak terjang bisnis oleh Gus Madkhan dan Haji Thariq, memberikan materi mulai kebangkrutan, punya hutang banyak, sedeka hhingga sampai bangkit dan membangun bisnis sampai menjadi sukses. Dengan adanya program tersebut, anak muda tertarik untuk mencoba membuka usaha atau membuka peluang bisnis agar dapat mencapai kesuksesan, menjadi kaya agar bisa bersedekah lebih banyak, bisa naik haji, menjadi orang sholeh dan kemudian masuk surga.

Kata Kunci: Rahasia sukses, teras dakwah, ngaji bisnis

\section{Pendahuluan}

Globalisasi dan abad informasi sekarang ini telah banyak mempengaruhi berbagai relasi dalam dunia kehidupan, termasuk kehidupan keberagamaan manusia, tidak terkecuali agama Islam. Relasi antara agama dan modernisme ditandai oleh berbagai permasalahan, dilema dan pertentangan. Era revolusi industri 4.0 telah menggiring kepada pelbagai kontradiksi dan paradoks dalam kehidupan keberagamaan. Perkembangan Information Technology (IT) memiliki efek yang sangat besar terhadap bagaimana agama itu kini difahami dan diritualkan.

Artikel ini membicarakan munculnya berbagai program dari gerakangerakan Islam kontemporer dalam menyampaikan dakwah. Muliaty Amin dalam penelitiannya menjelaskan bahwa strategi dakwah di zaman Nabi saw dan zaman kontemporer sekarang ini memang berbeda, namun esensi dakwahnya tetap sama, yakni menyeru kepada al-ma'ruf dan mencegah kemungkaran. IT di samping dapat digunakan sebagai media dakwah juga dapat digunakan sebagai sarana internet yang dengannya seseorang dapat bertukar informasi dan berkomunikasi dalam menyampaikan dakwah. Era kontemporer adalah masa kemajuan dunia dalam berbagai aspek kehidupan yang memukau, tetapi juga mengkhawatirkan. Aktualisasi dakwah melalui IT haruslah sejalan dengan esensi dakwah itu sendiri. Pemanfaatan IT melalui internet sebagai media berdakwah sangatlah efektif, karena didukung oleh sifat internet yang tidak terbatas ruang dan waktu. Materi keislaman dan dakwah bias disebarkan dengan cepat dan efisien. ${ }^{1}$

${ }^{1}$ Muliaty Amin, Information Technology (IT) dan Urgensinya Sebagai Media Dakwah Era Kontemporer, Jurnal Dakwah Tabligh (Vol. 14, No.2 , 2013), h. 183. 
Riyadi yang dalam penelitiannya juga mengemukakan bahwa menerapkan konsep paradigma baru model dakwah pengembangan masyarakat Islam menjadi sebuah keharusan yang perlu dilakukan. Kenyataan itu terasa semakin parah ketika asumsi-asumsi yang dibangun dalam memaknai dakwah selama ini kurang tepat, dimana dakwah hanya diartikan sebagai suatu kekakuan, masyarakat sebagai objek dakwah hanya diperlakukan menjadi sesuatu yang statis. Melihat hal itu, dakwah pengembangan masyarakat Islam sebagai salah satu komponen ujung tombak memberikan sentuhan alternatif model dakwah dengan lebih menjadikan pelaku dan masyarakat dakwah bersikap aktif, partisipatif dan progresif yang dibingkai oleh prisip-prinsip dakwah pengembangan masyarakat Islam (PMI), yaitu prinsip keutuhan, prinsip partisipasi, prinsip keterpaduan, prinsip berkelanjutan, prinsip keserasian dan prinsip kemampuan sendiri. ${ }^{2}$

Dakwah dikategorikan dalam dua tingkatan, yaitu dakwah tekstual yang hanya memberi materi tanpa perduli apakah audiens itu butuh atau tidak, yang kedua adalah dakwah kontekstual yang berusaha menjawab kebutuhan masyarakat. Persoalan yang dihadapi umat tidak hanya dapat diselesaikan hanya dengan mendengar ceramah saja melainkan perlu aksi nyata yang lebih konkrit seperti mengentaskan kemiskinan melalui pelatihan wirausaha dan mendukung pendidikan dalam mengurangi kebodohan.

Hidayat dalam artikelnya menjelaskan bahwa konsepsi riil Islam tentang agenda dakwah sebenarnya telah ada namun belum menjadi fokus untuk dikaji dan dikembangkan secara sistematis. Dakwah kontekstual berupaya menyentuh kesadaran individu bahwa Islam tidak hanya mengajak kepada bagaimana mencapai kesalehan individu melainkan juga bagaimana kesalehan tersebut dapat terimplementasi secara nyata menjadi kesalehan sosial. Problematika tersebut membutuhkan sentuhan dakwah yang lebih aplikatif sesuai dengan perkembangan zaman. Relevansi di sini menyangkut bagaimana membangun kesadaran sosial terkait tema-tema sosial kemasyarakatan yang sedang dihadapi umat Islam seperti kemiskinan, tingkat pendidikan umat Islam yang rendah, kesadaran ukhuwah Islamiyah, membangun toleransi dan sikap saling menghormati dalam konteks yang nyata. ${ }^{3}$

${ }^{2}$ Agus Riyadi, Formulasi Model Dakwah Pengembangan Masyarakat Islam, Jurnal ANNID A (Vol. 6 No. 2, 2014), h. 111.

${ }^{3}$ Amri Syarif Hidayat, Membangun Dimensi Baru Dakwah Islam: Dari Dakwah Tekstual Menuju Dakwah Kontekstual, Jurnal Risalah (Vol. XXIV, Ed. 2, 2013), h. 6. 
Rosyad dalam artikel Triantoro mengungkap tentang gerakan kebangkitan Islam kontemporer di kalangan anak muda di Bandung, dengan fokus pada kemunculan, perkembangan dan kekhasannya. Ia mengungkap tentang berbagai faktor yang melatarbelakangi kemunculan gerakan-gerakan Islam kontemporer. Kemudian menjelaskan tentang bagaimana dan mengapa anak muda beralih ke Islam serta bagaimana gerakan-gerakan itu dikembangkan oleh kalangan anak muda di Bandung. Hasil studinya menunjukkan bahwa kemunculan gerakan kebangkitan Islam saat ini merupakan kelanjutan dari tradisi pembaharuan dari gerakan Islam sebelumnya di Jawa seperti, Muhammadiyah dan PERSIS. Di samping itu, kemunculan gerakan Islam kontemporer juga dilatarbelakangi oleh berbagai masalah spiritual, sosial, politik dan budaya yang dihadapi muslim di Indonesia. ${ }^{4}$

Triantoro dalam penelitiannya juga menganalisis munculnya gerakan dakwah kontemporer di Yogyakarta, terutama pada lembaga sosial Teras Dakwah (TD) yang secara masif melakukan program dakwah populer di kalangan Muslim Yogyakarta. Artikelnya menjelaskan bentuk-bentuk kontestasi yang dilakukan TD terhadap otoritas keagamaan lama melalui berbagai program dakwah populer. Secara khusus, artikelnya membahas tentang konteks kemunculan gerakan dakwah kontemporer, bentuk kontestasi yang dilakukan oleh TD terhadap otoritas keagamaan lama, dan proses dakwah, kesalehan serta hijrah itu berlangsung. Hasil dari kajian tersebut menunjukkan bahwa kontestasi yang dilakukan oleh TD terhadap otoritas keagamaan lama dilakukan melalui upaya menciptakan ruang kesalehan populer dan hijrah bagi masyarakat. Di mana TD tidak berkontestasi secara politis, tetapi melakukan gerakan sosiokultural Islamis. ${ }^{5}$

Melihat latar belakang serta penelitian-penelitian sebelumnya yang barkaitan dengan Teras Dakwah, maka peneliti dalam penelitian ini menggunakan jenis penelitian deskriptif kualitatif, yaitu prosedur penelitian yang menghasilkan data deskriptif berupa kata-kata tertulis atau dari lisan orang-orang dan perilaku yang diamati atau dalam hal ini pendekatan diarahkan pada latar

${ }^{4}$ Dony Arung Triantoro, Dakwah dan Kesalehan: Studi Tentang Gerakan Teras Dakwah di Kota Yogyakarta, Jurnal Masyarakat \& Budaya (Vol. 20, No. 2, 2018), h. 274.

${ }^{5}$ Dony Arung Triantoro, Dakwah dan Kesalehan: Studi Tentang Gerakan Teras Dakwah di Kota Yogyakarta, h. 273. 
belakang objek dan individu tersebut secara holistik. ${ }^{6}$ Metode ini juga diartikan sebagai prosedur atau cara memecahkan masalah penelitian dengan memaparkan keadaan objek yang diselidiki (seseorang, lembaga, masyarakat dan lain-lain) sebagaimana adanya berdasarkan fakta-fakta yang aktual. ${ }^{7}$

Ada tiga unsur penting yang harus dipertimbangkan dalam menetapkan lokasi penelitian yaitu tempat, pelaku dan kegiatan. ${ }^{8}$ Penelitian tentang "Dimensi Baru Membimbing Umat dengan Dakwah Islam: Membongkar Rahasia Sukses Melalui Program Ngaji Bisnis di Lembaga Sosial Teras Dakwah Yogyakarta" berlokasi di Jalan Nitikan UH VI/413 Kelurahan Sorosutan Kecamatan Umbulharjo Kota Yogyakarta. Pendekatan penelitian ini diarahkan sebagai pengungkapan pola pikir peneliti dalam menganalisis sasarannya atau dalam ungkapan lain pendekatan ialah disiplin ilmu yang dijadikan acuan dalam menganalisis objek yang diteliti sesuai dengan logika ilmu itu. Adapun pendekatan yang digunakan yaitu pendekatan bimbingan dan konseling. Sumber data primer dalam penelitian ini yaitu Gus Madkhan Pengusaha Sugara Milk dan Haji Thariq Pengusaha Melon sebagai pemateri program "Ngaji Bisnis" di TD. Sumber data sekundernya yaitu buku, jurnal, internet. Penelusuran terhadap akun social media Teras Dakwah juga dilakukan sebagai data pendukung artikel ini. Metode pengumpulan data berupa observasi, wawancara dan dokumentasi. Langkah-langkah yang digunakan dalam menganalisis data pada penelitian melalui reduksi data, penyajian data dan penarikan kesimpulan.

Berdasarkan beberapa hasil penelitian sebelumnya serta dengan metodologi penelitian sebagaimana di atas, hal yang dibahas cenderung mengkaji aktualisasi gerakan dakwah melalui IT, pengembangan masyarakat Islam dalam konteks sosial, dakwah kontekstual dalam membangun kesadaran sosial, dan kontestasi yang dilakukan oleh lembaga sosial TD terhadap otoritas keagamaan lama. Oleh karena itu artikel ini menampilkan hal yang berbeda, dengan fokus membahas program "Ngaji Bisnis" pada lembaga sosial Teras Dakwah yang sebagian besar diminati oleh kaum anak muda. Dalam artikel ini, penulis menempatkan program "Ngaji Bisnis" sebagai ide baru dalam mendongkrak ketertarikan anak muda yang ingin menjadi kaya, sukses, naik haji, dan masuk surga.

${ }^{6}$ Lexy J. Moleong, Metode Penelitian Kualitatif Edisi Revisi (Bandung: PT Remaja Rosda Karya, 2006), h. 3.

${ }^{7}$ Hadari Nawawi, Martini Hadari, Instrumen Penelitian Bidang Sosial (Cet. II; Yogyakarta: Gadja Mada University Press, 1995), h. 67.

8S. Nasution, Metode Naturalistik Kualitatif (Bandung: Tarsinto, 1996), h. 43. 
Penulis merasa tertarik untuk melakukan penelitian di Lembaga Sosial Teras Dakwah karena aktivitas dakwahnya berbeda dengan gerakan dakwah yang lain, dimana kajian yang dilaksanakan bertempat di salah satu teras rumah seorang warga di Kampung Nitikan, Yogyakarta. Secara khusus, artikel ini akan mendiskusikan mengenai bagaimana proses pelaksanaan program "Ngaji Bisnis" di Lembaga Sosial Teras dakwah dan mengapa anak muda tertarik mengikuti program "Ngaji Bisnis" tersebut.

\section{Hasil dan Pembahasan}

\section{Gambaran Umum Lembaga Sosial Teras Dakwah}

Akhid Subiyanto adalah ketua sekaligus salah satu pendiri Lembaga Sosial Teras Dakwah yang merupakan aktivis dakwah yang sangat militan dan selalu bergerak dengan mobilitas tinggi untuk kepentingan agama dan umat. Secara resmi lembaga sosial Teras Dakwah berdiri pada tanggal 2 Maret 2014. Nama Teras Dakwah dipilih karena kata teras lebih fleksibel dan terbuka, kata ini lebih sederhana dan tidak mengikat. Berdakwah atau membuat sebuah kajian tidak harus di masjid, dari teras rumahpun juga bisa. Dengan nama ini, diharapkan masyarakat awam bisa tertarik untuk mengkaji ilmu Islam dan tidak merasa minder, kaku, dan bisa merasa nyaman untuk belajar Islam secara kaffah. Harapan terbesar TD sendiri adalah mampu membina masyarakat sekitar Nitikan pada khususnya dan Yogyakarta pada umumnya, serta mampu memberikan solusi kajian ilmu Islam yang sesuai tuntunan Alquran dan asSunnah. Kedepannya semoga TD menjadi salah satu wadah pelopor persatuan umat lintas harokah dan menjadi inspirasi gerakan dakwah di Nusantara, bahwa dakwah bisa berawal dari tempat sederhana namun bisa memberikan sesuatu yang bermakna.

Pada awalnya Penggerak Lembaga Sosial Teras Dakwah hanya ada 3 orang saja yang berasal dari Nitikan (bagian konsep, bagian publikasi dan bagian acara). Setelah memanfaatkan sosial media membuat publikasi secara umum, maka tahun 2013 satu per satu banyak jamaah yang bergabung dari berbagai latar belakang dan daerah di Yogjakarta. Rapat kerja perdana di awal tahun 2014 menetapkan kurang lebih 40 orang yang jadi pengurus, sekarang pada tahun 2019 jamaah kajian rutin sekitar 100-300 orang, khusus untuk tabligh akbar peserta mencapai 500-1.500 orang. Adapun kegiatan teras dakwah yaitu: Pertama, ngaji rutin (Ngaji Bisnis, Ngaji Teras, Ngaji Kreatif, dll) setiap hari rabu pukul 18:00-20:30 WIB. Kedua, Ngaji AMIDA (Akhwat dan Umi Muda) setiap hari 
jumat pukul 16:00-18:00 WIB. Ketiga, pengelolaan dan penyaluran zakat, infaq, wakaf dan sedekah (Teras Sedekah). Keempat, tabligh akbar bulanan. Kelima, mobilitas mobil dakwah (pembinaan ke desa binaan, penyaluran sedekah ke daerah minoritas, antar jemput ustadz, dll). Keenam, tahfidz untuk anak dan akhwat (Teras Tahfidz). Ketujuh, pelatihan dan training skill. Terakhir adalah program TD Archery Club (latihan memanah teras dakwah).

Rahasia sukses melalui ngaji bisnis di lembaga sosial Teras Dakwah ini disampaikan oleh Gus Madkhan dan Haji Thariq pada malam Kamis tanggal 24 April 2019 di teras dakwah pukul 18.00 Wib hingga selesei. Adapun hasil ngaji bisnis di teras dakwah sebagaimana yang di peroleh peneliti sekaligus sebagai pengunjung kajian teras dakwah sebagaimana berikut:

\section{Pemateri I Gus Madkhan}

Allah mampu mengangkat derajat siapa saja yang Allah kehendaki, saya dihadapan ikhwan dan akhwat semua bukan berarti lebih pintar, melainkan saya hanya berbagi cerita mengenai sepak terjang saya dalam dunia bisnis. Mengenai bisnis yang saya geluti, dan mengapa memilih jalan bisnis? Hal itu merupakan pelampiasan diri saya, dalam benak saya itu hanyalah mimpi. Memang saya tidak pernah mimpi jadi karyawan, cita-cita sejak kecil jadi pengusaha. Gus madkhan besarkan di panti asuhan.

Saya bermimpi dari awal ingin jadi pengusaha tidak pernah mimpi jadi karyawan. Pengusaha tidak diatur orang, sebenarnya saya termotivasi oleh sabda nabi "sebaik manusia adalah yang bermanfaat bag orang lain" ialah orang yang memiliki bebas finan sial atau memiliki kelebihan. Itulah yang menjadi motivasi saya, meskipun saya terlahir dalam keadaan miskin tapi saya berhak menentukan nasib, masadepan tidak akan pernah berubah nasib kita kalau tidak kita yang merubahnya sendiri.

Membangun bisnis adalah hal yang paling mudah, awalnya saya membangun usaha tanpa modal banyak. Melainkan hanya melihat pengusaha di jogja yang sukses harus beberapa tahun mereka membangun bisnis, tentunya mereka membutuhkan proses yang panjang. Dahulu saat saya masih Smt 1 saya sudah jadi pengusaha, nyablon stiker pada tahun 2000-an kemudian bisnis rental VCD meteor garden, aadc dll. Semuanya ada rintangan dan asyik, setelah itu saya juga pernah jualan beras, setiap hari menjual telur 2 ton, mendatangkan telur dari blitar, produksi tas 1000 pcs perbulan, kemudian tahun kelima sugara milk 
berdiri, mimpi saya visualkan, dimana sebelum berdiri segera milk yang saya visualkan dalam bentuk doa. Karena waktu itu saya tidak punya apa-apa, kemudian saya punya segudang ilmu pun juga karena nekat. Punya ilmu, setiap bisnis yang kita jalani harus ada ilmunya. Ilmu ini saya dapat dari teman, jalanjalan dll. Penjualketan di Malang saya tanya, sehari bisa jual berapa, itu saya tidak malu, belajar pada siapapun dan dimanapun, karena itu adalah guru kita. Ketika ke tempat orang jangan banyak bicara, tapi jadilah murit yang banyak mendengar. Orang banyak bicara akan banyak bicaranya aksinya tidak ada.

Saya 6 tahun lalu pernah mengalami dimana keadaan sangat terpuruk, saya tidak punya apa-apa, yang saya punya adalah hutang yang sangat banyak. Kemudian saya mencari guru pengusaha yang saya dekati, mereka ada seminar, kajian, mereka saya datangi untuk dapat ilmu saat sedang terpuruk. Karena saya saat terpuruk ingat dengan pesan suan kalijaga yakni berkumpullah dengan orang soleh karena mereka memberikan energi positif, jangan hanya tiduran d kamar, pergilah ke majlis taklim yang bisa menimbulkan fikiran positif. Ilmu tdk hanya tentang dagang atau menjual prodak.

Mengenai Sugara Milk adalah begini, saya waktu itu terinspirasi dengan susu yang ada di jogja yang lagi ngehit. Saya melihat seorang juragan yang keluar dari masjid kemudian ia naik mobil merci putih. Besok pagi saya langsung beli susu 1/5 liter tapi tetap belum enak, selanjutnya juga belum enak sampai $25 x$ saya mencoba. Kemudian saya melibatkan Allah dengan segala hal. Mengajukan mimpi dengan meminta proposal pada Allah yakni proposal sugara milk. Padahal saat itu saya sedang menanggung utang 1.2 Miliar rupiah dan saya juga pengangguran.

Sebelum saya berbisnis sugara milk, pada waktu kuliah saya jualan sembako sampai omset saya 80 Juta rupiah perhari hancur karna Allah. Dari situlah saya bangkit dan pengen buka sugara milk, kemudian saya bilang pada Allah bahwa saya butu uang sekian ya Allah. Karena saya juga harus berhadapan dengan dep kolektor. Tindakan melibatkan Allah, jangan hanya mengajukan tapi juga mendekat dengan menjalani perintah dan menjauhi larangannya serta menjalankan sunnah Nabi kita. Sebagaimana Firman Allah yang berbunyi "Ud'uni astajib lakum".

Istri nanya mas modalnya dari mana, kemudian saya jawab katanya allah kaya, saya minta Allah. Saya tetap semangat saya cari tempat, kemudian saya melakukan riadoh selama 40 hari yakni menjalankan sholat 5 waktu dimasjid tidak pernah telat. Siapapun dan apapun kita entah miskin kaya apapunlah, kita punya 
hak untuk sukses. Kita berhak mimpi untuk sukses, tidak ada sarat untuk seskses. Mimpi-mimpi kalian dijadikan suatu proposal pada Allah, saya usaha dari 0 alhamdulillah Allah mampukan saya. Impian kita serahkan pada Allah. Saya ingin buka sugara milk. Minta ampun, sholat taubat dari hutang-hutang saya yang mengandung riba. Saya tidak akan hutang bank lagi. Hajat saya, saya sampaikan pada Allah, riadhoh dengan mohon berdoa pada allah. Sampaikan dalam sujud, dan kita juga harus meminimalisir dosa. Saya riyadhah dengan menjalankan sholat 5 waktu di masjid tanpa terlambat. Hal itu sesuai dengan sabda nabi "jadikan sholat dan sabar sebagai penolongmu" dan pastilah 40 hari solusi diberikan oleh Allah. Selain itu kerjakan Sholat Duha, kemudian saya bilang pada Allah kalau rizki saya haram ambil saja ya Allah. Yang mampu adalah Allah,minta restu orang tua, silaturahim kepada saudara" kita dan kemudian saya kembali memulai usaha sugara milk dengan modal 2.5 Juta rupiah, hasil dari penjualan cincin kawin saya.

\section{Pemateri II Haji Thariq}

Materi dari Haji Thariq ini tidak terlalu lama karena sudah terlalu malam. Ia hanya menyampaikan inti-intinya, bahwa ia dahulu adalah seorang marbot masjid daerah taman siswa. Ia mengatakan kalau dahulu ke jogja hanyalah merantau tidak punya apa-apa dan tidak punya siapa-siapa. Saya pertama adalah menjadi marbot masjid, menjadi pembersih kamar mandi dan toilet masjid daerah taman siswa.

Pertama kali mengawali usaha adalah ikut jualan orang sambil belajar. Terus saya mengikuti dan belajar bagaimana manajemen dalam berbisnis. Setelah la tau bgaimana ilmu jualan, barulah ia memulai berjuaalan dengan modal dari hasil kerja. Berawal jualan dari lapak-lapak di pinggir jalan, ambil kemudian jual, ambil lagi kemudian jual. Hingga waktu itu saya mempunyai banyak kios buah dan meraup untung ratusan juta. Namun suatu ketika ia pernah hutang dan itulah awal dari kehancuran bisnisnya sampai ia jual mobil. Saat itu ia kemudian umroh dan sepulang dari umroh ia dapat tawaran lapak kios di tengah pasar yang letaknya strategi. Itu adalah milik temannya waktu sama-sama jualan buah, yang kemudian di jual ke saya, saya bilang tidak ada uang kemudian ia bilang dibayar seadanya nanti lunasinnya sampai anda punya uang.

Itulah awal kebangkitan saya hingga saya menjadi pengusaha buah dan membuka banyak kios dan menjadi pendistribusi buah kawasan Yogyakarta. Hingga saya membangun rumah sehabis kurang lebih 4 Miliar rupiah dan mendirikan tempat lahan pertanian untuk belajar menanam merawat sampai bisa 
memanen buah melon. Motivasi saya adalah "Allah tidak akan merubah keadan suatu kaum hingga ia merubahnya sendiri". Dari situlah motivasi untuk terus bangkit hingga saya bisa seperti ini "tuturnya". Dalam keadaan saya yang sepeti ini, saya secara finansial sudah tercukupi, saya kemungkinan dulu kurang zakatnya dan saat ini di sebelah rumah saya saya bangun tempat singgah untuk para pendakwah untuk tempat istirahat kajian dan ngaji mengenai ilmu agama islam, disitu juga saya sediakan fasilitas yang insya Allah nyaman dan juga saya sediakan mobil apabila memang digunakan untuk urusan dakwah ummat.

Dari cerita para pemateri ngaji bisnis yang diselenggarakan di lembaga sosial teras dakwah tersebut, peneliti memiliki asumsi-asumsi yang sekiranya sesuai dengan hasil penelitian yang bedasarkan kenyataan yang ada dilapanga. Dari hal di atas ada 3 pokok dasar yang harus diketahui yakni; pertama, kesuksesan, kedua, menjadi kaya agar bisa bersedekah lebih banyak, ketia, bisa naik haji, keempat, menjadi orang sholeh dan kemudian masuk surga.

Jadi dapat dikatakan bahwa kemampuan berwirausaha (entrepreuneurial) merupakan fungsi dari perilaku kewirausahaan dalam mengkombinasikan kreativitas, inovasi, kerja keras, dan keberanian menghadapi risiko untuk memperoleh peluang. Faktor-faktor tersebut maka akan lahirlah perilaku kewirausahaan yang diantaranya meliputi kreativitas, inovasi, kerja keras serta keberanian dalam menghadapi risiko.

\section{Mengapa Anak Muda Tertarik Ngaji Bisnis di Lembaga Sosial Teras Dakwah?}

Menjadi kaya, sukses, banyak sedekah, umroh, naik haji, soleh kemudian bila meninggal nanti masuk surga. Tentunya itu menjadi impian setiap manusia, tidak hanya yang tua-tua saja tapi yang muda-mudapun juga ingin menjadi kaya, sukses, banyak sedekah, naik haji, soleh dan masuk surga. Pertanyaanya, siapa yang hidup didunia ini tidak ingin jadi orang suskses, kaya, bisa sedekah dan bias naik haji? Tentunya semua orang ingin akan hal tersebut, sebagaimana hal itu juga ajaran nabi, nabi adalah sosok yang sukses, kaya, banyak menolong, banyak sedekah dan ia juga berwira usaha yakni dengan berdagang kesana kemari.

Dari kedua pemateri di atas, peneliti menarik benang merah yakni memang benar ukuran orang itu masuk surga adalah seberapa soleh orang tersebut. Namun, bagaiaman bila kesalean itu hanya diukur dari kaya, sukses,

sedekah, naik haji apakah itu termasuk social secularization sebagaimana kritik Bryan S. Turner terhadap Jose Casanova dalam "Islam, Public Religion and the 
Secularization Debate". Hal itu ditunjukan dengan adanya pendapat Bryan S Turner, bahwa jalan keluar dari sekularisasi yang sempit tahun 1960-an adalah untuk menguji interaksi antara kesalehan pribadi dan regulasi publik yaitu antara deprivatisasi dan pietisasi. ${ }^{10}$ Mengapa, kesalehan yang mereka ukur dengan sukses, kaya, sedekah, haik haji adalah disebut dengan peitization, karena mereka mengukur kesalehan hanya dengan syariat saja.

Tidak menutup kemungkinan mereka kaum muda baik ikhwan maupun akhwat yang tertarik mengikuti ngaji bisnis di lembaga sosial teras dakwah adalah mereka yang memang ingin sukses atau mereka yang ingin berhijrah. Yang selanjutnya karena kemungkinan bentuk ngaji di teras dakwah disedain dengan berbentuk kekinian yang sesuai dengan anak muda saat ini. Karenanya mereka sangat tertarik dengan gaya pemateri yang juga tidak terkesan ceramah, melainkan diskusi bareng. Salah satunya adalah diskusi, siapa yang bertanya atau menjawab dari pemateri dapat hadiah baik berupa buku, melon, sugara milk dan itu tergantung pemateri siapa yang memberikan materi di teras dakwah tersebut. Karena atas slogan sukses, kaya, sedekah, soleh dan masuk surga tersebut yang di komparasikan dengan sunnah Nabi menjadikan mereka yang ingin atau yang baru saja berhijrah menjadi sangat tertarik dan rutin mengikuti kajian tersebut.

Rasulullah mendapatkan jiwa entrepreneur sejak beliau usia 12 tahun. Ketika itu pamannya Abu Thalib mengajak melakukan perjalanan bisnis di Syam negeri yang meliputi Syiria, Jordan dan Lebanon saat ini. Sebagai seorang yatim piatu yang tumbuh besar bersama pamannya beliau ditempa untuk tumbuh menjadi wirausahawan yang mandiri. Ketika usia 17 tahun Muhammad telah diserahi wewenang penuh untuk mengurusi seluruh bisnis pamannya. Ketika usia menginjak 20 tahun adalah merupakan masa tersulit dalam perjalanan bisnis rasulullah SAW. Beliau harus bersaing dengan pemain senior dalam perdagangan regional. Namun kemudian titik keemasan entrepreneurship Muhammad SAW tercapai ketika usia antara 20-25 tahun Bastoni dalam Wijayanti. ${ }^{11}$

Viktor Kiam, seorang pakar enterpreneur, sama berkomentar bahwa jiwa enterpreneur/wirausaha perlu diberikan kepada anak sejak dibangku sekolah, karena filosofi kewirausahaan dapat melatih anak lebih mandiri, jeli melihat peluang, sehingga punya daya cipta yang lebih kreatif. Dalam konteks Islam,

${ }^{10}$ Bryan S. Turner, Islam Public Religions and the Secularization Debate, editor by Gabriele Marraci, Muslim Societies and the Challenge of Secularizzzation, Volume I (Singapore: Springer, 2010). h. 16

${ }^{11}$ Ratna Wijayanti, Membangun Enterpreneurship Islami dalam Perspektif Hadits, Cakrawala: Jurnal Studi Islam (Vol. 13, No. 1, 2018). h. 37 
Nabi Muhammad SAW adalah wirausahawan sejati yang memiliki kemerdekaan, kebebasan dan memupuk kepercayaan pada diri sendiri melalui pengalaman yang menyenangkan ketika hidup di pedalaman dalam asuhan ibu susuannyaHalimah, dan masa pahit dan penuh kepedihan karena terlahir sebagai seorang yatim dan ditinggal ibunya-Aminah ketika ia baru berusia enam tahun. Muhammad kemudian dibesarkan oleh kakeknya yang juga tidak begitu lama bersamanya. Abu Thalib, pakcik kandungnyalah kemudian mengambil alih pengasuhan atas Muhammad yang masih berusia kurang dari 9 tahun. Dan inilah modal psikologis yang paling kokoh sebagai landasan sikap, dan prilaku wirausahawan beliau dikemudian hari dan menjadi referensi penelitian para ahli kewirausahaan, diceritakan bahwa, Muhammad baru berusia dua belas tahun ketika pergi ke Syria berdagang bersama Abu Thalib, pamannya. Ketika pamannya meninggal dunia, beliau tumbuh dan berkembang sebagai wirausahawan yang mandiri dengan melakukan perdagangan keliling di kota Makkah dengan rajin, penuh dedikasi pada usahanya. ${ }^{12}$

Muhammad SAW adalah sosok pengusaha sukses dan kaya. Di antara informasi tentang kekayaan beliau sebelum kenabian adalah jumlah mahar yang dibayarkan ketika menikahi Khadijah Binti Kuwalaid. Konon, beliau menyerahkan 20 ekor unta muda sebagai mahar. Dalam riwayat lain, ditambah 12 uqiyah (ons) emas. Suatu jumlah yang sangat besar jika dikonversi ke mata uang kita saat ini.

Dengan demikian, Muhammad SAW telah memiliki kekayaan yang cukup besar ketika beliau menikahi Khadijah. Kayaan itu kian bertambah setelah menikah, karena hartanya digabung dengan harta Khadijah dan terus dikembangkan melalui bisnis (perdagangan). Dari situlah para akhwat ingin di khitbah oleh ikhwan yang mengikuti sosok Rasulullah tersebut dan sebaliknya para ikhwan ingin menjadi soleh, kaya dan sukses.

\section{Bisnis dalam Perspektif Islam}

Tujuan dakwah adalah membuat perubahan dalam diri manusia, baik untuk membentuk sifat adil maupun aktual, baik individu maupun keluarga masyarakat, way of thinking atau cara berpikirnya berubah, way of life atau cara hidupnya berubah menjadi lebih baik ditinjau dari segi kualitas maupun kuantitas. Intinya dakwah bertujuan untuk mengubah sikap mental dan tingkah laku manusia yang kurang baik menjadi lebih baik atau meningkatkan kualitas

\footnotetext{
12 Ratna Wijayanti, Membangun Enterpreneurship Islami dalam Perspektif Hadits, Cakrawala: Jurnal Studi Islam (Vol. 13, No. 1, 2018). h. 39
} 
iman dan Islam seseorang secara sadar dan timbul dari kemauannya sendiri tanpa terpaksa. Selanjutnya dalam Ekonomi, Islam menempatkan bahwa tujuan ekonomi tidak hanya kesejahteraan duniawi saja, tapi juga untuk kepentingan yang lebih utama yaitu kesejahteraan ukhrawi.

Hasil penelitian Hatimah dan Kurniawan menyimpulkan bahwa integrasi dakwah dan ekonomi Islam bertujuan agar manusia memperoleh kebahagian dunia dan akhirat (Falah). Ekonomi Islam dan dakwah merupakan sarana untuk menyeru manusia agar dalam tindak tanduknya dalam kegiatan muamalah terutama dalam kegiatan perekonomian sesuai dengan nilai-nilai ajaran Islam. Selanjutnya dakwah ekonomi Islam dalam membangun ekonomi umat dilaksanakan dengan cara mengubah pola pikir masyarakat yang berideologi konsumtif menjadi produktif agar bisa menggerakaan roda perekonomian. Pengembangan teknologi meyesuaikan dengan kebutuhan zaman agar mampu bersaing. Oleh karena itu, sudah sepatutnya kita memanfaatkan lembaga dakwah secara optimal dalam membangun ekonomi umat. ${ }^{13}$

Bisnis dalam syariah Islam pada dasarnya termasuk kategori muamalah yang hukum asalnya adalah boleh berdasarkan kaidah fikih "Al-Ashlu fil muamalah alibahah batta yadullad dalilu 'ala tabrimiba" artinya pada dasarnya segala hukum dalam muamalah adalah boleh, kecuali ada dalil yang melarangnya. Kita juga perlu mengetahui konsep ekonomi Islam dalam penjualan suatu produk yang menekankan kehalalan, manfaat dan mematuhi prinsip dasar ekonomi syariah secara makro yang terbebas dari tujuh unsur maysir (judi), aniaya (zhulm), gharar (penipuan), haram, riba (bunga), iktinaz atau ihtikar. ${ }^{14}$

Metode dakwah Islam di era modern pada prakteknya mengalami banyak perkembangan dalam banyak hal, khususnya terkait dengan sarana dan cara yang dipakai dalam berdakwah. Hal ini menunjukkan bahwa Islam memang relevan dan selalu ada untuk memenuhi kebutuhan umat. Berdasarkan hasil penelitian yang dilakukan oleh Fuaidi dapat diambil kesimpulan bahwa fikih muamalah adalah salah satu bagian penting dari sarana dan materi dakwah yang dipraktekkan sekarang ini. Kenyataan tersebut didasarkan pada fakta bahwa perbankan syariah menjadi bagian tak terpisahkan dari sistem ekonomi dunia khususnya di negara-negara dengan mayoritas penduduk muslim seperti di Indonesia sedangkan sistem tersebut tidak dapat lepas dari keilmuan fikih

${ }^{13}$ Husnul Hatimah dan Rahmad Kurniawan, Integrasi Dakwah dan Ekonomi Islam, Jurnal Al Qardh (Vol. V, Nomor 1, 2017), h. 1.

${ }^{14}$ Ahmad Mardalis dan Nur Hasanah, Multi-Level Marketing (MLM) Perspektif Ekonomi Islam, FALAH Jurnal Ekonomi Syariah (Vol. 1, No.1, 2016), h. 33-38. 
muamalah itu sendiri. Maka dari itu, selama ada sistem ekonomi Islam dan perbankan syariah berdiri, maka fikih muamalah menjadi hal yang urgen. Selanjutnya, relevansi fikih muamalah dalam perkembangan dakwah Islam ini dielaborasi lebih lanjut dengan membahas sejumlah karakteristik dakwah modern yang setiap karakteristik tersebut terdapat nilai dan prinsip yang ada di fikih muamalah. ${ }^{15}$

Komarudin dalam penelitiannya menjelaskan bahwa Bandung dikenal sebagai suku atau etnik religius terbukti dari penampakan wujud vitalitasnya dalam refleksi aktivitas formalnya. Hal itu dapat dilihat dari perjalanan dinamika keagamaan yang intensitasnya cukup kental seperti aktivitas ibadah yang semarak, contohnya formalistik shalat, meriahnya ramadhan, banyak majelis taklim atau banyaknya kaum muslimin yang melaksanakan ibadah haji dalam setiap tahun, baik secara kualitas maupun kuantitasnya. Hal ini tentu mempengaruhi kegiatan bisnisnya yang dimana merupakan manajemen modern berorientasi profesional kewirausahaan. Penelitian ini memberikan bukti bahwa etika bisnis yang diterapkan oleh Suku Sunda mempengaruhi pedoman kerangka setiapkebijakan bisnis. Terlebih lagi, faktor teologis memainkan peran penting dalam mendorong manusia untuk menjadi sukses dalam bisnis. CV. Batu Gunung Padakasih (BGP) yang terletak di Cikancung-Bandung, Kabupaten Tapin, telah mewakili banyak temuan yang signifikan mengenai hubungan antara etika dan teologi bisnis sosial dalam kebijakan yang dapat dianggap sebagai hubungan kausal dalam keberhasilan bisnis. $^{16}$

Pendekatan yang dilakukan oleh Dawam Rahardjo dalam artikel Efendi Nur menyandarkan landasan hukum Islam sesuai dengan karakteristik aliran transformasi sosial yang menekankan hubungan yang harmonis antara Islam dan negara dengan memanfaatkan lembaga-lembaga kemasyarakatan. Bahkan teori ekonomi Dawam Rahardjo menyangkut sistem moral dan fondasi ekonomi dengan menawarkan nilai-nilai Islam, contohnya konsep ZIS (Zakat, Infaq Shadaqoh), agar dapat diaplikasikan dalam kehidupan umat Islam. Dakwah sebagai langkah menuju transformasi masyarakat tidak hanya berorientasi terhadap peningkatan hubungan vertikal kepada Allah semata melainkan juga memupuk kualitas diri sebagai individu

\footnotetext{
${ }^{15}$ Isyrokh Fuaidi, Implementasi Fikih Muamalah dalam Pengembangan Media Dakwah di Era Modern, Jurnal Islamic Review (Vol. IV, No. 1, 2015), h. 35-36.

${ }^{16}$ Didin Komarudin, Bisnis Orang Sunda: Studi Teologi dalam Etika Bisnis Orang Sunda, ISLAM REALITAS: Journal of Islamic \& Social Studies (Vol. 3, No. 2, 2017), h. 122.
} 
dalam menuju pembentukan pemberdayaan umat. Karena sebagai makhluk Allah yang dipenuhi dengan rasio serta akhlak, manusia haruslah mampu melangkah menuju proses perubahan sebagai natural of law yang dipertegas dengan dalil bahwa Allah tidak akan merubah kondisi umat bila makhluk itu sendiri tidak memiliki upaya menuju perubahan ke arah yang lebih maju.

Pemberdayaan ekonomi umat mengandung tiga misi. Pertama, misi pembangunan ekonomi dan bisnis yang berpedoman pada ukuran-ukuran ekonomi dan bisnis yang lazim dan universal. Kedua, pelaksanaan etika dan ketentuan hukum syariah yang harus menjadi ciri kegiatan ekonomi umat Islam. Ketiga, membangun kekuatan ekonomi umat Islam sehingga menjadi sumber dana pendukung dakwah Islam yang dapat ditarik melalui zakat, infaq, sodaqoh, wakaf serta menjadi bagian dari pilar perekonomian Indonesia. Sedangkan transformasi (perubahan) sosial berlangsung sangat kompleks. Agama seringkali disebut sebagai faktor pendorong terjadinya perubahan ke arah positif. Hal tersebut merupakan indikasi urgensi agama bagi masyarakat yang menimbulkan keterikatan terhadap religious values. Sikap semacam ini akan mendorong terhadap pembentukan perilaku-perilaku keberagamaan yang lebih mendalam pada diri masing-masing individu. Namun disisi lain agama terkadang juga disebut sebagai faktor penghambat terhadap perubahan, ini disebabkan agama sebagai way of life memiliki aturan-aturan yang tersimbolkan. Sehingga ketika proses perubahan berjalan dan ternyata tidak sesuai dengan simbol-simbol tersebut maka secara otomatis akan terjadi penolakan. ${ }^{17}$

\section{Makna Enterpreneurship}

Menurut Peter F. Drucker dikutip Machfoed dalam Wijayanti kewirausahaan adalah kemampuan untuk menciptakan sesuatu yang baru dan berbeda. Orang tersebut melakukan kegiatannya melalui organisasi bisnis yang baru ataupun bisa pula dilakukan dalam organisasi bisnis yang sudah ada. Jiwa kewirausahaan mendorong orang untuk mendirikan dan mengelola usaha secara profesional. Hendaknya minat tersebut diikuti dengan perencanaan dan perhitungan yang matang. ${ }^{18}$ Dia juga menyatakan bahwa yang dimaksud entrepreneurship adalah "aktivitas yang secara konsisten dilakukan guna

${ }^{17}$ Ma'mun Efendi Nur, Dakwah Sosial Ekonomi dalam Pandangan Dawam Rahardjo, Jurnal Ilmu Dakwah (Vol. 37, No. 1, 2017), h. 3-4.

${ }^{18}$ Ratna Wijayanti, Membangun Enterpreneurship Islami dalam Perspektif Hadits, Cakrawala: Jurnal Studi Islam (Vol. 13, No. 1, 2018). h. 41-42 
mengkonversi ide-ide yang bagus menjadi kegiatan usaha yang menguntungkan".

Entrepreneurship dalam Islam mempunyai pengertian bahwa kewirausahaan adalah segala aktivitas bisnis yang diusahakan secara perniagaan dalam rangka memproduksi suatu barang atau jasa dengan jalan tidak bertentangan dengan syariat.

Pertama, kewirausahaan dianggap sebagai jihad fii sabilillah (strong efforts to do good things in the name of Allab).Kedua,entrepreneur dianggap sebagai amal Sholeh (good deeds) karena kegiatan entrepreneurship menyediakan pendapatan kepada individu, menawarkan kesempatan kerja kepada masyarakat, sehingga mengurangi kemiskinan. Dimana kemiskinan adalah salah atu dari persoalan sosial.Ketiga,entrepreneurship juga meningkatkan perekonomian masyarakat. Dengan melakukan kebajikan melalui Entrepreneurship, akan mendorong terciptanya hubungan yang harmonis antara individu dan individu serta akan membantu menjaga hubungan yang lebih baik antara individu dengan tuhannya. Keempat, meningkatkan kualitas hidup, hidup lebih nyaman menguatkan kedudukan sosio-ekonomi negara, agama dan bangsa. Kelima, membantu mengembangkan khairun ummah (masyarakat terbaik, yang produktif dan maju (progressive). Keenam, pedoman utama dalam kewirausahaan islami. Agar kegiatan kewirausahaan dianggap sebagai ibadah' diantaranya adalah: ${ }^{19}$

1. Tetap melakukan Ibadah, Sholat, dan Puasa dan ibadah-ibadah lain di antara kesibukan sebagai entrepreneur.

2. Hindari melakukan hal-hal yang dilarang oleh Allah.

3. Pelajari sikap seorang pengusaha muslim yang baik.

4. Bisnis yang baik perencanaan strategi (tidak pergi dari ajaran Islam).

5. Mengetahui aturan (hukum) bermuamalah secara Islami.

\section{Konsep Berwirausaha/Berbisnis Syariah Nabi Muhammad SAW}

Nabi Muhammad SAW mengajarkan melakukan berwirausaha dan transaksi dilakukan secara jujur, adil dan jangan membuat konsumen kecewa.Konsep berwirausaha dalam islam dikenal dengan istilah tijarah (berdagang atau bertransaksi). Konsep berwirausaha dalam Islam yang mengacu

\footnotetext{
${ }^{19}$ Ratna Wijayanti, Membangun Enterpreneurship Islami dalam Perspektif Hadits, Cakrawala: Jurnal Studi Islam (Vol. 13, No. 1, 2018). h. 42
} 
pada konsep wirausaha Nabi Muhammad SAW yang perlu ditiru dan diterapkan umat muslim, sebagai berikut ${ }^{20}$ :

\section{Shiddiq}

Shiddiq artinya adalah berkata benar dan jujur. Jujur dalam hal berkaitan dengan pada saat bertransaksi dengan nasabah, mengedepankan kebenaran informasi, menjelaskan keunggulan barang. Jika ada kelemahan atau cacat pada produk,maka disampaikan kepada calon pembeli.

\section{Amanah}

Amanah yaitu sifat kepercayaan baik dari darisisi internal maupun eksternal. Maknanya adalah sekecil apapun upaya danperbuatan manusia, baik atau buruk, tetapmendapat perhatian dari Allah dan akanmendapatkan balasan yang kembali pada dirinyasendiri. Manusia bebas memilih jalan yang salah,musyrik, munkar yang akan mengantarkannya padakerusakan, kesesatan dan kehancuran moral.Sebagai konsekuensinya, jika manusia berbuatkebaikan, maka dia diberi pahala dan kehidupanyang baik.Sifat amanah memainkan peranan yangfundamental dalam ekonomi dan bisnis, karenatanpa kredibilitas dan tanggung jawab,kehidupan ekonomi dan bisnis akan hancur.

\section{Tabligh}

Tabligh yaitu kemampuan menyampaikan,kemampuan berkomunikasi efektif. Maknanya adalah para wirausahawan harusmampu melatih diri dalam menyampaikan ide danproduk bisnisnya, harus mampu menyampaikan danmempromosikan keunggulan-keunggulan produkdengan menarik dan tepat sasaran, serta mampumengkomunikasikannya secara tepat dan mudahdipahami oleh siapapun yang mendengarkannya.Hal yang paling penting harus mampumenjembatani antara pihak perusahaan dan pihak customer.

\section{Fathanah}

Sifat fathonah merupakan memiliki kecerdasan dalam berbisnis. Artinya dalam berwirausaha sifat fathanah adalah bahwa semua kegiatan-kegiatan dalam suatu perusahaan harus dilakukan dengan kecerdasan, dengan memanfaatkan potensi akal dan pikiran yang ada untuk mencapai tujuan. Memiliki sifat jujur, benar, dan bertangguang jawab tidak cukup dalam mengelola bisnis secara

${ }^{20}$ Norvadewi, Bisnis Dalam Perpektif Islam (Telaah Konsep, Prinsip dan Landasan Normatif), Jurnal Ekonomi dan Bisnis Al TIJARY (Vol. 01, No. 01, Desember 2015). h. 36 
profesional. Para pelaku wirausaha juga harus memiliki sifat fathanah, yaitu sifat cerdas, cerdik, dan bijaksana agar usahanya labih efektif dan efisien.

\section{Sukses Secara Islam dan Tipsnya}

Kunci sukses bisnis secara Islam mungkin bisa kita dapat contoh dari Nabi kita yaitu Nabi Muhammad SAW, karena beliau merupakan salah satu pebisnis yang sukses dan berbisnis sesuai dengan jalan yang di ridhoi Allah SWT. Beberapa tips yang diberikan dan contoh dari Nabi Muhammad SAW dalam bisnis antara lain:

1. Cara di dalam Bisnis:

Pertama: jujur di dalam bisnisnya, kedua: berprinsip pada nilai Illahi, ketiga: bertanggung jawab, keempat: keadilan dan keseimbangan, kelima: tidak hanya mengejar keuntungan, keenam: berniat baik di bisnisnya, ketujub: branding/menjaga nama baik

2. Cara Merintis Bisnis :

Pertama: fokus dan konsentrasi, mempunyai goal dan rencana yang jelas, kedua: merintis bisnis dari nol, ketiga: tidak mudah putus asa, keempat: berusaha menjadi trend center, kelima: inovatif, keenam: memahami kondisi dan analisa pasar, ketujub: Kemampuan merespon strategi pesaingnya, kedelapan: belajar menguasai pasar, kesembilan: mampu memanagement organisasi secara efektif, kesepulub: bisa menghilangkan mental blocking, kesebelas: mampu menarik dan meyakinkan pemilik modal untuk ikut serta dalam bisnis yang dilaksanakannya 3. Cara Menjalankan Bisnisnya:

Pertama: bekerja sama (bersinergi), kedua: kerja pintar, kreatif dan visioner, ketiga: menerapkan kesepakatan win-win-solution (saling menguntungkan, dan tidak ada yang dirugikan), keempat: bekerja dengan prioritas, kelima: tidak melakukan monopoli, keenam: selalu berusaha dan tawakal, ketujuh: tepat waktu, kedelapan: berani ambil resiko.

Selain yang berkenan dengan hal-hal diatas, yang ingin menjadi anggota tetap teras dakwah juga harus menjadi donatur aktif bagi teras dakwah baik berupa makanan maupun uang atau barang yang bisa dimanfaatkan untuk teras dakwah dan ummat. Selain itu juga ada sedekah untuk parkir dan pengunjung saat acara usai. Sedekah-sedekah selalu di tanamkan disana kalau ingin menjadi orang sukses. Ingin sukses dan kaya ya harus sedekah, seberapa banyak kita memberi juga sebanyak itulah kita akan menuai. 


\section{Penutup}

Salah satu kesempurnaan Islam adalah dengan mengharuskan kepada umatnya agar bisa hidup mandiri dengan bekerja atau berbisnis dengan jalan yang benar. Islam tidak hanya mengajarkan untuk beribadah saja, tetapi Islam juga mengajarkan umatnya untuk mandiri dan bekerja keras salah satunya dengan Entrepreneurship atau berbisnis. Bisnis dalam Islam mempunyai pengertian bahwa kewirausahaan adalah segala aktivitas bisnis yang diusahakan secara perniagaan dalam rangka memproduksi suatu barang atau jasa dengan jalan tidak bertentangan dengan syariat.

Ngaji Bsnis tersebut banyak digemari, karena mempunyai slogan bahwa orang yang sholeh adalah orang yang sukses, kaya, banyak sedekah dan naik haji. Karena itulah banyak ikhwan dan akhwat yang masih muda mengikuti kajian di lembaga sosial teras dakwah di daerah Nitika Yogyakarta. 


\section{Bibliografi}

Amin, Muliaty. (2013). Information Technology (IT) dan Urgensinya Sebagai Media Dakwah Era Kontemporer. Jurnal Dakwah Tabligh. Vol. 14, No. 2.

Fuaidi, Isyrokh. (2015). Implementasi Fikih Muamalah dalam Pengembangan Media Dakwah di Era Modern. Jurnal Islamic Review. Vol. IV, No. 1.

Hatimah, Husnul. (2017). Rahmad Kurniawan. Integrasi Dakwah dan Ekonomi Islam. Jurnal Al Qardh. Vol. V, Nomor 1.

Hidayat, Amri Syarif. (2013). Membangun Dimensi Baru Dakwah Islam: Dari Dakwah Tekstual Menuju Dakwah Kontekstual. Jurnal Risalah. Vol. XXIV, Ed. 2.

Komarudin, Didin. (2017). Bisnis Orang Sunda: Studi Teologi dalam Etika Bisnis Orang Sunda. ISLAM REALITAS: Journal of Islamic \& Social Studies. Vol. 3, No. 2.

Mardalis, Ahmad. (2016). Nur Hasanah. Multi-Level Marketing (MLM) Perspektif Ekonomi Islam. FALAH Jurnal Ekonomi Syariah. Vol. 1, No.1.

Moleong, Lexy J.Metode Penelitian Kualitatif Edisi Revisi. Bandung: PT Remaja Rosda Karya, 2006.

Nasution, S. Metode Naturalistik Kualitatif. Bandung: Tarsinto, 2006.

Nawawi, Hadari. Martini Hadari. Instrumen Penelitian Bidang Sosial. Yogyakarta: Gadja Mada University Press, 1995.

Norvadewi. (2015). Bisnis Dalam Perpektif Islam (Telaab Konsep, Prinsip dan Landasan Normatif), Jurnal Ekonomi dan Bisnis Al TIJARY Vol. 01, No. 01.

Nur, Ma'mun Efendi. (2017). Dakwah Sosial Ekonomi dalam Pandangan Dawam Rahardjo. Jurnal Ilmu Dakwah. Vol. 37, No. 1.

Profil Lembaga Sosial Teras Dakwah Yogyakarta 2019

Riyadi, Agus. (2014). Formulasi Model Dakwah Pengembangan Masyarakat Islam, Jurnal ANNID A. Vol. 6 No. 2.

Triantoro, Dony Arung. (2018). Dakwah dan Kesalehan: Studi Tentang Gerakan Teras Dakwah di Kota Yogyakarta. Jurnal Masyarakat \& Budaya. Vol. 20, No. 2.

Turner Bryan S. (2010). Islam Public Religions and the Secularization Debate, editor by Gabriele Marraci, Muslim Societies and the Challenge of Secularizzzation, Volume I. Singapore: Springer

Wijayanti Ratna. (2018).Membangun Entrepreneurship Islami dalam Perspektif Hadits, Cakrawala: Jurnal Studi Islam Vol. 13, No. 1. 